
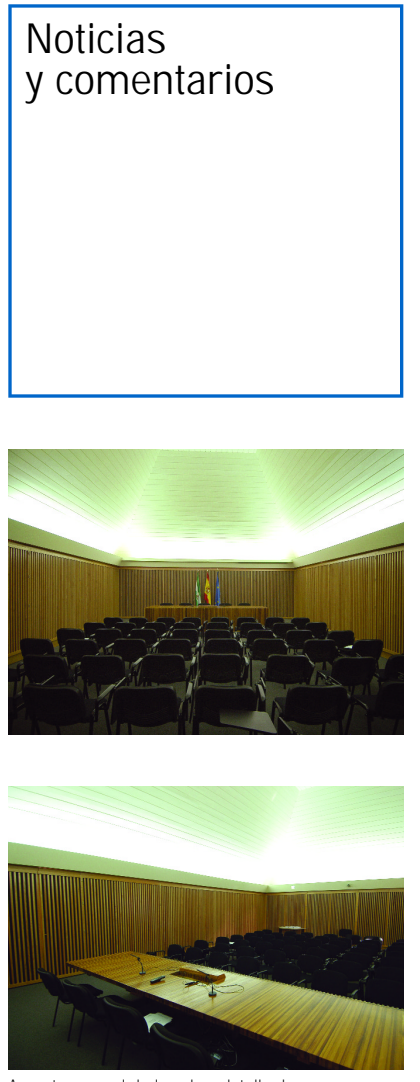

Aspecto general de la sala y detalle de mesa. Imagen: Eugenio Fernández

Noticias del IAPH

\title{
Nueva imagen para la sala de conferencias del IAPH
}

En la zona fabril del Conjunto Monumental de la antigua Cartuja de Santa María de las Cuevas de Sevilla, el Instituto Andaluz del Patrimonio Histórico dispone de una sala con una espacialidad caracterizada por su techo troncopiramidal, que, desde la intervención en el edificio en 1989 por parte de los arquitectos Luis Marin y Emilio Yanes, ha venido utilizándose con asiduidad como sala de conferencias en multitud de cursos y seminarios. El uso continuado de la sala para este tipo de actos ha supuesto para el IAPH una experiencia ya dilatada en el tiempo que le ha llevado a desear para esta sala una mayor adecuación para la funcionalidad especializada a la que se dedica. Entre las dotaciones que se deseaban introducir, se encontraba una cabina de traducción simultánea para atender la necesidad que surge en ocasiones de traducir en tiempo real a un conferenciante extranjero; además de ello, se detectaban algunos problemas como la condensación de vapor de agua en los techos y la reverberación sonora de la sala, debidos a las condiciones de espacialidad y geometría de la cubrición, que hacen que se concentren gran cantidad de ondas acústicas en determinados puntos de la misma. Asimismo el gran volumen de aire de la sala $\left(500 \mathrm{~m}^{3}\right)$ y las propiedades físicas de los materiales con los que estaba revestida, la mayoría de ellos acústicamente reflectantes, favorecian la reverberación sonora, aspectos que resultaba importante corregir.

La intervención realizada plantea una ubicación remota de la cabina de traducción, en un espacio externo a la sala de conferencias, conectada a ésta mediante un equipamiento audiovisual, con lo que se consigue no desvirtuar la espacialidad original de la sala y poder acondicionarla, en la medida posible, para mejorar su comportamiento en cuanto a condensaciones y reverberación acústica.

En origen estaba pavimentada con un terrazo micrograno realizado in situ, las paredes enfoscadas y pintadas en blanco hasta una altura de 2,85 $\mathrm{m}$, punto en donde a partir de una moldura tiene su arranque la cubierta de forma troncopiramidal revestida de duelas de madera lacadas en blanco.

Dispone de seis ventanas que no garantizan el total oscurecimiento de la sala, aspecto que el $\mathrm{IAPH}$ considera deseable en un lugar donde se celebran conferencias y seminarios con proyección de imágenes.

Para intentar paliar los problemas de reverberación se ha optado por revestir los paramentos verticales y el suelo de la sala con materiales absorbentes, con lo que se conseguirá "secar acústicamente" la sala, a la vez que se plantea una gran cornisa de instalaciones para resolver la disposición de los conductos de impulsión y extracción de aire y las instalaciones eléctricas y audiovisuales. De este modo, se refuerza con una nueva envolvente continua interior la zona baja de la sala, destacando más fuertemente la singularidad del techo. Esta nueva piel interior se resuelve mediante un trasdosado de placas acústicas constituidas por listones de madera de haya de $4 \mathrm{~cm}$ de lado con entrecalles de $4 \mathrm{~cm}$, todo ello trasdosado con un material absorbente e ignífugo, lana de roca con un velo de color negro en su cara vista. Coplanariamente a este revestimiento de las paredes, se disponen unas puertas superpuestas a las ventanas existentes, de manera que se posibilita hacer uso de la sala con oscurecimiento total 0 , abriendo estas puertas, con iluminación natural. En el fondo de la sala se ha dispuesto un mueble, revestido de igual manera que el resto de la sala, que oculta todos los sistemas audiovisuales necesarios, al igual que las máquinas evaporadoras reutilizadas que disponía la sala y que garantizan la climatización de la misma.

La nueva imagen de la sala se complementa con el diseño de una mesa para conferencias y presidencia de actos culturales, construida con listones de madera maciza de iroko.

Debemos significar el cuidado y profesionalidad de las empresas participantes en la ejecución de la obra, lo que ha permitido un nivel de acabado satisfactorio.

$>$ Título del proyecto: Acondicionamiento de sala de conferencias en el IAPH

> Promotor: Instituto Andaluz del Patrimonio Histórico

$>$ Autores: TEJIDO I PASTOR, arquitectos. Ignacio

Pastor Segovia y Javier Tejido Jiménez

$>$ Empresas: Obras y Montajes Peñarroya / INELEC S.L (Comunicación Visual y Sistemas Electrónicos)

> Fecha de ejecución: 2004

Ignacio Pastor Segovia

Javier Tejido Jiménez

Arquitectos 